\title{
Menilik kebijakan pengolahan limbah B3 fasilitas pelayanan kesehatan selama pandemi COVID-19 di Provinsi Jawa Barat
}

\author{
Pricillia Putri Ervian Sitompul* \\ Fakultas Hukum Universitas Gadjah Mada, Yogyakarta \\ *Koresponden E-mail: pricilliaputri99@mail.ugm.ac.id
}

(Diterima 13 Oktober 2020|Disetujui 07 Januari 2021|Diterbitkan 30 Januari 2021)

\begin{abstract}
Managing hazardous medical waste in COVID-19 era has its own challenges. Acknowledging such challenges, the provincial Government of West Java suggested every health care facility in West Java to collaborate with PT Jasa Medivest or other companies that provide waste management services. Commonly, they use incinerator machines as their main tools to demolish the hazardous medical waste. Although it is a commonly used method to demolish medical waste, there are several issues that need to be marked. Therefore, this study aims to observe and analyze the advantages and disadvantages of the suggestion made by the Provincial Government from the perspective of environmental and economic sustainability. This study also proposes several alternative methods to overcome the problems by reflecting on methods that other countries had successfully conducted. This study uses a normative legal research method, in which secondary data are obtained from library research. The data obtained are analyzed and explained using descriptive methods. The results revealed that in the terms of environmental sustainability, the use of incineration method has the potential to perpetuate air pollution. Meanwhile, in terms of financial efficiency, collaborating with PT Jasa Medivest or other companies that provide waste management services incurs a fairly high cost. Hence, it is necessary to evaluate and consider other waste management options.
\end{abstract}

Keywords: COVID-19, medical waste, waste management

Pada tanggal 30 Januari 2020, World Health Organization (WHO) menetapkan Coronavirus Disease 2019 (COVID-19) sebagai Public Health Emergency of International Concern (PHEIC) atau Kedaruratan Kesehatan Masyarakat Yang Meresahkan Dunia (KKMMD) (World Health Organization, 2020). Berdasarkan laporan WHO terkait situasi epidemiologi global, Asia Tenggara menjadi kawasan kedua yang paling terdampak oleh adanya pandemi COVID-19 setelah Amerika, diikuti dengan Eropa, Mediterania Timur, Pasifik Barat, dan Afrika. Di kawasan Asia Tenggara sendiri, Indonesia menjadi negara kedua dengan jumlah kasus terbanyak, dimana hingga bulan September 2020 telah mencapai 240.687 kasus (World Health Organization, 2020). Adapun pihak-pihak yang paling rentan untuk terkena infeksi adalah mereka yang berhubungan dekat dengan pasien COVID-19. Sebagai contoh adalah para tenaga kesehatan yang bekerja di lingkungan Fasilitas Pelayanan Kesehatan (Fasyankes). Oleh karena itu, tindakan pencegahan dan mitigasi di lingkungan Fasyankes memegang peranan besar untuk memutus rantai penularan COVID-19 (Direktorat Jenderal Pencegahan dan Pengendalian Penyakit (P2P), 2020). Salah satu bentuk mitigasi yang dapat diterapkan adalah optimalisasi manajemen pengelolaan limbah B3 Fasyankes yang efektif, efisien, dan sesuai dengan protokol kesehatan.

Sedikit melihat kebelakang, dalam keadaan normal pengelolaan limbah B3 Fasyankes memang sudah wajib untuk ditangani secara terpisah dan dengan prosedur yang tepat sebagai tanggung jawab pihak pengelola Fasyankes. Akan tetapi, pada tataran implementasi kerap ditemukan pengelola Fasyankes yang mengabaikan aspek kelestarian lingkungan ketika menjalankan proses pengolahan limbah B3 yang dihasilkan. Akibatnya, tidak jarang ditemukan limbah medis yang bercampur dengan limbah rumah tangga dan dibuang ke tempat pembuangan akhir tanpa ada pengolahan khusus sebelumnya (Chaerul, 2013). Atas dasar tersebut, terdapat urgensi untuk membenahi metode pengolahan limbah B3 medis yang selama ini diterapkan, terlebih jika mengingat bahwa saat ini Indonesia sedang berada dalam kondisi khusus akibat menyebarnya COVID-19.

Pengelolaan limbah B3 Fasyankes di era COVID-19 memiliki tantangan tersendiri. Limbah B3 medis adalah barang atau bahan sisa hasil kegiatan medis yang tidak digunakan kembali yang berpotensi terkontaminasi oleh zat yang bersifat infeksius atau kontak dengan pasien dan/atau petugas di Fasyankes yang menangani pasien COVID-19. Adapun diantaranya meliputi masker bekas, sarung tangan bekas, perban bekas, tisu bekas, plastik bekas minuman dan makanan, kertas bekas makanan dan minuman, alat suntik bekas, set infus bekas, Alat Pelindung Diri (APD) bekas, sisa makanan pasien dan lain-lain, berasal dari kegiatan pelayanan di Unit Gawat darurat (UGD), ruang isolasi, ruang Intensive Care Unit (ICU), ruang perawatan, dan ruang pelayanan lainnya.

Berkaca pada China, volume pembuangan limbah B3 medis yang semula hanya berkisar pada $4.90,8$ ton/hari meningkat hingga menyentuh angka $6.066,8$ ton/hari (Astuti, 2020). Sebagai contoh, untuk Provinsi Hubei sendiri diperkirakan telah mengalami peningkatan volume timbulan limbah yang semula hanya berkisar pada 40 ton/hari menjadi 240 ton/hari (Prasetiawan, 2020). Untuk Indonesia sendiri, jika mengacu pada timbulan sampah per pasien di China, menggunakan skenario intervensi, maka volume timbulan limbah di Indonesia diperkirakan mencapai 
8.589 ton/hari dan belum termasuk sampah rumah tangga Orang Dalam Pemantauan (ODP) (Astuti, 2020).

Sayangnya dalam tataran praktis, masih ditemukan pelbagai kendala dalam mengoptimalkan pengolahan atau pemusnahan limbah B3 medis. Salah satunya adalah karena terdapat kesenjangan antara jumlah limbah yang kian meningkat dengan ketersediaan serta kapasitas fasilitas pengolah limbah medis yang tersedia. Hingga saat ini di Indonesia baru terdapat 10 jasa pengelolaan limbah medis berizin dengan kapasitas pengelolaan limbah kurang lebih 170 ton per hari dan 87 rumah sakit yang memiliki alat insinerator untuk mengolah limbah medisnya sendiri dengan kapasitas sekitar 60 ton per hari (Humas UGM, 2020). Di Provinsi Jawa Barat sendiri hingga kini baru terdapat 5 rumah sakit yang telah memiliki teknologi insinerator dan mengantongi izin dari Kementerian Lingkungan Hidup dan Kehutanan (KLHK) untuk melakukan pengelolaan limbah secara mandiri. Ironisnya, keterbatasan tersebut seringkali mengakibatkan sebagian besar limbah yang tidak mampu diolah kemudian dibakar atau dibuang di ruang terbuka bahkan di aliran sungai atau kali-kali (Damanhuri, 2009).

Untuk mengatasi kesenjangan yang ada, sebagaimana dilansir dalam halaman web resmi Direktur Penilaian Kinerja Pengelolaan Limbah B3 dan Limbah Non B3, Sinta Saptarina Soemiarno menyatakan bahwa, respon dan upaya solusi pemecahan kesenjangan kapasitas pemusnahan limbah medis lainnya, adalah pembangunan 32 Fasilitas Pemusnah Limbah B3 medis di tahun 2020 - 2024 dengan Anggaran Pendapatan dan Belanja Negara (APBN) KLHK yang akan diserahkan dan dikelola oleh pemerintah daerah (Kementerian Lingkungan Hidup dan Kehutanan, 2020). Namun, apabila dikaji lebih lanjut, muncul pertanyaan apakah respon yang demikian sudah tepat untuk mengatasi permasalahan yang ada. Pasalnya, proses pengadaan teknologi insinerator tidaklah mudah serta memakan waktu cukup lama. Selain itu, pemilihan lokasi pembangunan fasilitas insinerator juga memerlukan waktu dan perencanaan yang matang. Berdasarkan permasalahan tersebut, Penulis kemudian tertarik untuk melakukan penelitian dan menelisik kebijakan pengolahan limbah B3 Fasyankes selama pandemi COVID-19 Di Provinsi Jawa Barat.

\section{BAHAN DAN METODE}

Penelitian ini dilaksanakan di Provinsi Jawa Barat pada bulan April sampai dengan bulan September 2020. Seluruh data yang disajikan dalam penelitian ini adalah data yang terkumpul dari bulan April hingga bulan September 2020. Penelitian ini menggunakan jenis penelitian normatif, yaitu yaitu penelitian yang sumber datanya berasal dari normanorma hukum yang terdapat dalam peraturan perundang-undangan, putusan pengadilan serta hukum yang ada dalam masyarakat (Ali, 2009). Sejalan dengan jenis penelitian yang digunakan, Penelitian ini menggunakan pendekatan peraturan perundangundangan pendekatan perbandingan (Ibrahim, 2006).

Pendekatan peraturan perundang-undangan dilakukan dengan menelaah regulasi yang berkaitan dengan pengolahan limbah B3 Fasyankes, sedangkan pendekatan perbandingan dilakukan dengan mengkaji konsep pengolahan limbah yang dilakukan di beberapa provinsi di China sebagai negara pembanding yang dinilai kebijakannya telah berhasil memberangus timbulan limbah B3 Fasyankes berlebih.

Komponen yang diteliti pada penelitian ini adalah komponen input dan komponen proses. Komponen input terdiri dari kebijakan, ketersediaan sarana dan prasarana, serta aspek pembiayaan dan komponen proses pengolahan akhir atau pemusnahan limbah B3. Penelitian ini menggunakan metode penelitian kualitatif-interaktif yang digunakan menitikberatkan pada analisis logis serta deskripsi dan penyimpulan naratif atau kata-kata (Hamdi, 2014). Kemudian untuk teknik pengumpulan data yang digunakan adalah studi kepustakaan (library research) karena data yang digunakan merupakan data-data sekunder (Soekanto, 1984). Terhadap bahan yang telah dikumpulkan kemudian diolah menggunakan metode deduktif untuk kemudian dianalisis menggunakan metode kualitatif. Terhadap analisis yang dihasilkan akan dituangkan ke dalam bentuk penulisan secara deskriptif. Terakhir, penarikan kesimpulan dilakukan dengan mengkaji hasil analisis untuk kemudian memfokuskannya kepada suatu kejelasan konsep, sudut pandang, serta penjabaran alternatif pilihan yang dapat diambil untuk mengurangi permasalahan yang akan timbul dari metode pengelolaan limbah yang dipilih.

\section{HASIL}

Berdasarkan penelitian pada komponen input yang dilakukan, dapat diketahui bahwa Provinsi Jawa Barat telah memiliki regulasi yang memuat pengaturan terkait pengolahan atau pemusnahan limbah B3 di wilayahnya. Adapun regulasi yang dimaksud adalah Peraturan Daerah Provinsi Jawa Barat No 23 Tahun 2012 tentang Pengelolaan Limbah Bahan Berbahaya dan Beracun di Jawa Barat. Untuk ketentuan pengolahan sendiri secara spesifik dimuat dalam Pasal 16 peraturan daerah a quo yang mengatakan bahwa pengolahan limbah B3 dilakukan oleh penghasil atau badan usaha yang melakukan kegiatan pengolahan limbah B3, sesuai ketentuan peraturan perundangundangan dan wajib memiliki izin dari menteri yang menyelenggarakan urusan pemerintahan di bidang lingkungan hidup.

Sedangkan dalam komponen proses, pengolahan limbah B3 Fasyankes dalam keadaan normal dilakukan menggunakan mesin insinerator/ autoklaf/gelombang mikro. Mengingat bahwa penelitian ini memfokuskan pada pengolahan limbah B3 Fasyankes di era pandemi COVID-19, Surat Edaran Menteri Lingkungan Hidup dan Kehutanan No.SE.2/MENLHK/PLB.3/3/2020 mewajibkan 
pengolahan limbah menggunakan insinerator. Dalam kondisi darurat, pengguna teknologi insinerator tidak diwajibkan untuk memiliki izin. Artinya ada proses analisis dampak lingkungan yang dikesampingkan di sini. Kemudian untuk abu/residu yang dihasilkan harus dikemas dalam wadah yang kuat untuk dikirim ke penimbun berizin. Bila tidak memungkinkan untuk dikirim ke penimbun berizin, abu/residu insinerator dapat dikubur sesuai konstruksi yang ditetapkan pada Peraturan Menteri Lingkungan Hidup dan Kehutanan Nomor P.56/Menlhk-Setjen/2015 tentang Tata Cara Persyaratan Teknis Pengelolaan Limbah Bahan Berbahaya dan Beracun dari Fasilitas Pelayanan Kesehatan.

Berdasarkan hasil penelitian, ditemukan bahwa pemilihan penggunaan insinerator memiliki beberapa kekurangan apabila dilihat dari sudut pandang kelestarian lingkungan dan pembiayaan. Dari segi kelestarian lingkungan, abu hasil proses insinerasi berpotensi melanggengkan pencemaran udara karena mengandung komponen zat yang dapat membahayakan kesehatan makhluk hidup. Kemudian dari segi pembiayaan, biaya penyerahan abu insinerator ke perusahaan penyedia jasa layanan pengolahan limbah berbahaya terbilang cukup tinggi.

Berdasarkan permasalahan yang ditemukan, penelitian ini mengusung beberapa langkah strategis yang sekiranya dapat digunakan sebagai alternatif solusi untuk mengisi kekurangan-kekurangan yang dimiliki dari penggunaan fasilitas insinerator di Provinsi Jawa Barat. Khususnya di era pandemi COVID-19, dimana pemerintah dituntut untuk bekerja lebih cepat namun tetap efektif dan efisien khususnya dalam mengeluarkan kebijakan-kebijakan jangka pendek. Langkah strategis yang dimaksud diusung dengan berkaca pada keseriusan Pemerintah Daerah di Kota Wuhan yang sudah jauh lebih komprehensif dalam menangani lonjakan volume limbah selama pandemi berlangsung. Adapun dua (2) hal utama yang setidaknya patut di contoh ialah; (1) terkait bagaimana Pemerintah Kota Wuhan mampu mengoptimalkan pemanfaatan berbagai fasilitas pengolahan limbah B3 yang sudah ada, dan (2) terkait bagaimana Pemerintah Kota Wuhan mensiasati minimnya alokasi dana untuk kegiatan pengolahan limbah melalui pengaplikasian skema Public Private Partnership dalam bentuk BuildOperate-Transfer Agreement.

\section{PEMBAHASAN}

\section{Metode Pengolahan Limbah B3 Fasyankes di Provinsi Jawa Barat pada Era COVID-19 Dalam Status Quo}

Dalam rangka menghadapi tantangan pengolahan limbah B3 Fasyankes di Indonesia, Kementerian Lingkungan Hidup dan Kehutanan (KLHK) mengeluarkan Surat Edaran Menteri Lingkungan Hidup dan Kehutanan No. SE.2/MENLHK/PLB. 3/3/2020 tentang Pengelolaan Limbah Infeksius (Limbah B3) dan Sampah Rumah Tangga yang secara garis besar mengatur mengenai prosedur pelaksanaan penanganan limbah infeksius yang berasal dari Fasyankes dan sampah rumah tangga ODP serta pengelolaan sampah rumah tangga dan sampah sejenis rumah tangga. Lebih lanjut, KLHK juga mengeluarkan surat No. S.167/MENLHK/PSL B3.3/3/2020 kepada Kepala Badan Nasional Penanggulangan Bencana (BNPB) yang menekankan pada pemusnahan limbah B3 sesegera mungkin baik itu dilakukan oleh jasa pengolahan limbah B3 dan/atau rumah sakit yang memiliki insinerator. Berdasarkan surat a-quo, limbah medis penanganan COVID-19 dikategorikan sebagai limbah B3 karena memiliki karakteristik infeksius. Maka dari itu pengelolaannya ikut tunduk pada Peraturan Pemerintah No. 101 Tahun 2014 tentang Pengelolaan Limbah Bahan Berbahaya dan Beracun dan Peraturan Menteri LHK No. 56 Tahun 2015.

Ruang lingkup pengelolaan limbah B3 meliputi kegiatan pengurangan, penyimpanan, pengumpulan, pengangkutan, pemanfaatan, pengolahan, dan/atau penimbunan. Dalam melakukan pengolahan limbah B3 Fasyankes, ada beberapa pilihan metode yang dapat dipertimbangkan untuk diambil diantaranya; a) dikelola langsung oleh pemerintah; b) dilakukan oleh pihak ketiga, dan; c) rumah sakit memiliki insinerator sehingga dapat memastikan pemusnahan limbah B3 secara mandiri. Dari berbagai pilihan tersebut, kewenangan untuk menetapkan dan melaksanakan kebijakan mengenai limbah B3 ada pada pemerintah daerah. Oleh karena itu, pemerintah daerah memegang peranan penting dalam mengarahkan kebijakan pengelolaan limbah B3 yang minim resiko.

Untuk mencegah adanya penumpukan limbah B3 Fasyankes selama COVID-19, Pemerintah Daerah Provinsi Jawa Barat menyarankan agar Fasyankes bekerja sama dengan PT Jasa Medivest selaku penyedia jasa layanan pengelolaan limbah yang merupakan Badan Usaha Milik Daerah (BUMD) (HuMas Jawa Barat, 2020). Adapun pijakan legal yang memungkinkan pemilihan metode a quo adalah Pasal 32 Peraturan Daerah Provinsi Jawa Barat No. 23 Tahun 2012 yang mengatakan bahwa Pemerintah Daerah dapat bermitra dengan badan usaha, baik dalam negeri maupun luar negeri dalam pengelolaan limbah B3, sesuai ketentuan peraturan perundangundangan. Hubungan kemitraan tersebut dituangkan dalam bentuk kesepakatan dan/atau perjanjian antara Pemerintah Daerah dan badan usaha yang bersangkutan.

Metode pengolahan limbah B3 yang digunakan oleh PT Jasa Medivest adalah insinerasi, yaitu metode pemusnahan limbah menggunakan suhu tinggi untuk mengoksidasi komponen-komponen limbah yang mudah terbakar menggunakan teknologi insinerator. Skema ini merupakan metode manajemen pengolahan limbah yang paling umum digunakan dan dipandang lebih menguntungkan. Pertama, pemanfaatan teknologi insenerator sangat kompatibel untuk mengolah limbah dalam waktu yang relatif singkat dan mampu mereduksi sebagian besar berat limbah secara substansial (hingga 75\%) dan volume (hingga 90\%) 
(Dai, 2016). Kedua, metode ini relatif lebih efisien karena tidak memakan lahan jika dibandingkan dengan metode sanitary landfill, dimana ketersediaan lahan kosong menjadi faktor penentu keberhasilan metode ini (Mohajit, 2019). Padahal, sebagaimana yang diketahui, ketersediaan lahan di provinsi provinsi padat penduduk sangat terbatas. Terakhir, proses insinerasi dapat menghasilkan "by product" berupa gas panas flue gases yang bisa dipulihkan kembali (recovery) untuk membangkitkan energi listrik (Prasetiyadi, 2018).

Selain itu secara normatif, beberapa negara yang telah berhasil melewati fenomena peningkatan volume limbah B3 Fasyankes, salah satunya China merekomendasikan agar limbah B3 yang dihasilkan oleh pasien COVID-19 di berbagai Fasyankes harus dimusnahkan menggunakan teknologi incinerator bersuhu tinggi (Chinese Government, 2020). Sejalan dengan rekomendasi pemerintah China, metode pemusnahan yang sama kemudian diaplikasikan oleh pemerintah Indonesia yang dituangkan ke dalam Surat Edaran Menteri Lingkungan Hidup dan Kehutanan No. SE.2/MENLHK/PLB.3/3/2020 dan Surat No.S.167/MENLHK/PSLB3.3/3/2020 kepada Kepala Badan Nasional Penanggulangan Bencana (BNPB). Sebagai komando utama di bidang pengolahan limbah B3, pemerintah pusat mewajibkan seluruh Fasyankes penghasil limbah B3 di daerah manapun untuk mengolah limbah menggunakan teknologi insinerator.

Pengolahan Limbah B3 Fasyankes di Provinsi Jawa Barat pada Era COVID-19 Ditinjau dari Perspektif Kelestarian Lingkungan dan Prespektif Pembiayaan

\section{Prespektif Kelestarian Lingkungan}

Sayangnya, apabila dilihat dari perspektif kelestarian lingkungan, pemilihan metode insinerasi untuk mengolah limbah B3 Fasyankes berpotensi melanggengkan pencemaran udara. Berdasarkan penelitian yang dilakukan oleh Siyang Dai, proses pembakaran limbah menggunakan teknologi insenerator akan mengubah limbah heterogen menjadi residu yang lebih homogen berupa gas buang, fly ash, dan bottom ash. Komposisi residu tersebut masuk kedalam kategori polutan yang dapat menyebabkan pencemaran lingkungan karena mengandung $\mathrm{HCl}$, SO2, NOx, HF, Hg, Cd dan Dioxin (Dai, 2016).

Potensi adanya pencemaran lingkungan menjadi semakin tinggi, ketika pemilihan lokasi pembangunan instalasi insinerator tidak strategis. Sebagai contoh pembangunan instalasi dilakukan pada lahan yang letaknya berdekatan dengan pemukiman penduduk maupun sumber mata air. Hal ini dikarenakan kadar kelarutan air yang rendah serta waktu paruh biologis dioksin yang lama, sehingga bahkan konsentrasi kecil saja di air dan di tanah berpotensi terkonsentrasi ke dalam rantai makanan dan berkembang pada level yang lebih berbahaya bagi kesehatan manusia. Peristiwa ini pernah dialami oleh penduduk Kota Wuhan, dimana fly ash yang dihasilkan dari proses insinerasi limbah B3 tidak diolah secara baik sehingga mengakibatkan pencemaran air. Padahal fly ash tersebut mengandung dioksin berbahaya yang dapat mempengaruhi kesehatan makhluk hidup jika meminum atau menggunakan air yang terkontaminasi ( $\mathrm{Hu}, 2015)$.

\section{Prespektif Pembiayaan}

Di sisi lain, jika dilihat dari perspektif pembiayaan, pemilihan penggunaan jasa layanan pengelola limbah ini berkonsekuensi menimbulkan biaya baru untuk proses pengangkutan dan pengolahan akhir limbah. Hingga saat ini, pengelolaan limbah B3 Fasyankes oleh pihak ketiga belum memiliki patokan biaya karena ada banyak variabel yang menentukan biaya pengolahan limbah tersebut diantaranya jarak, volume timbulan, dan kebutuhan lain yang diperlukan untuk kegiatan pengolahan limbah. Ketidakpastian nominal atau unit cost setiap kilogram limbah dapat mengakibatkan lonjakan biaya yang tidak dapat diperhitungkan sebelumnya. Selain itu, Fasyankes juga terkendala oleh program Jaminan Kesehatan Nasional (JKN) di mana penggantian biaya dan pembayaran tidak sepenuhnya berjalan sesuai rencana, sehingga mempengaruhi kemampuan untuk mengelola limbah B3 (Direktorat Penilai Kinerja Pengelolaan Limbah B3 dan Limbah Non B3, 2018).

Masalah pembiayaan lain yang kemudian muncul adalah dana pembiayaan pembuangan abu insinerator yang harus dibuang di landfill kelas 1 (satu). Adapun biaya penyerahan abu insinerator ke perusahaan penyedia jasa layanan pengolahan limbah berbahaya yaitu PT Prasadha Pamunah Limbah Industri (PPLI), berkisar pada $\mathrm{Rp} 2,5$ juta/drum ditambah dengan biaya pengangkutan yang dibebankan kepada jasa pengolah limbah B3 Fasyankes dan pembayaran harus dilakukan dimuka sehingga terbilang cukup mahal. Namun, menurut jasa pengelola, biaya yang dibebankan kepada Fasyankes sudah merupakan harga yang wajar. Komponen biaya yang terbesar adalah bahan bakar, biaya pengangkutan (jarak) dan biaya untuk pemusnahan abu insinerator di PPLI (Direktorat Penilai Kinerja Pengelolaan Limbah B3 dan Limbah Non B3, 2018). Berdasarkan pertimbangan dan latar belakang sebagaimana diuraikan diatas, maka perlu dilakukan adaptasi strategi yang efisien dan efektif. Salah satunya dengan mengaplikasikan metode yang telah berhasil dilakukan oleh negara lain dengan tetap menyesuaikan pengaplikasiannya dengan ketentuan, kondisi, serta karakteristik sosial-budaya di Indonesia khususnya dalam konteks penelitian ini adalah di Jawa Barat.

\section{Alternatif Kebijakan Metode Pengolahan Limbah Fasyankes yang Dapat Diterapkan di Provinsi Jawa Barat pada Era COVID-19 \\ Ketika penyakit pandemi seperti COVID-19 muncul, diperlukan strategi jangka pendek yang komprehensif untuk mengatasi timbulan berlebih limbah B3 Fasyankes. Untuk itu, tidak hanya bergantung pada fasilitas insinerator yang sudah ada, Pemerintah China juga menghadirkan berbagai macam}


fasilitas penunjang yang bersifat sementara sebagai bentuk strategi darurat jangka pendek. Adapun fasilitas yang dimaksud meliputi tempat transit dan tempat pengolahan sementara. Sebagai contoh, beberapa instalasi insinerator sementara telah dibangun di beberapa pusat layanan kesehatan seperti di Rumah Sakit Jinyitan, Rumah Sakit Huoshenshan dan Rumah Sakit Leisheshan (Yu, 2020).

Berkaca pada bagaimana Pemerintah Kota Wuhan mengatasi penumpukan timbulan limbah B3 Fasyankes, strategi jangka pendek serupa dapat diterapkan oleh Pemerintah Daerah Provinsi Jawa Barat. Bukan dengan menghadirkan atau mendirikan fasilitas insenerator baru melainkan mengoptimalkan pemanfaatan fasilitas pengolahan limbah B3 yang sudah ada semaksimal mungkin. Salah satunya adalah dengan memanfaatkan fasilitas kiln yang dimiliki oleh pabrik-pabrik semen.

Pemerintah Daerah Provinsi Jawa Barat dapat mengadakan hubungan kemitraan dengan perusahaan pabrik semen yang berkedudukan di wilayah Jawa Barat seperti PT Indocement Tunggal Perkasa Tbk, PT Holcim Indonesia Tbk, PT Semen Padang dan PT. Cemindo Gemilang sebagai salah satu strategi darurat jangka pendek. Hal ini sangat dimungkinkan karena sejatinya sudah pernah diterapkan pada tahun 2017 oleh KLHK melalui Keputusan Menteri LHK SK.176/2018 untuk menanggulangi kondisi darurat penghentian kegiatan pengolahan limbah B3 Fasyankes oleh pihak ketiga di Provinsi Jawa Barat karena banyak pihak penyedia jasa yang kurang mentaati persyaratan perizinan pengolahan limbah.

Secara lebih spesifik, suhu tinggi yang dihasilkan oleh teknologi co-processing dalam fasilitas kiln semen dapat dimanfaatkan untuk melakukan pengolahan limbah B3 Fasyankes. Teknologi coprocessing adalah teknologi bersih karena dengan pembakaran pada temperatur tinggi (di atas $1450^{\circ} \mathrm{C}$ ), material limbah dapat musnah tanpa meninggalkan residu dan gas buang yang keluar cerobong menjadi satu dengan gas hasil pembakaran dan reaksi kalsinasi. Sayangnya terdapat keterbatasan dalam proses ini yakni tidak direkomendasikan untuk pengolahan jenis limbah yang mudah meledak, bersianida, radioaktif, infeksius, klorin tinggi (Pamungkas, 2010).

Optimalisasi pengolahan limbah B3 dengan menggunakan menggunakan kiln semen jauh lebih mendukung aspek pengelolaan lingkungan bersih yaitu pengurangan emisi pencemaran udara akibat SO2. Proses pembakaran melalui kiln semen dinilai jauh lebih menguntungkan karena kondisi pembakaran yang stabil, netralisasi potensi adanya secondary waste dalam bentuk zat berbahaya lainnya, waktu retensi yang lebih lama, menyebabkan emisi gas rumah kaca dan biaya yang lebih rendah (Zhu, 2019). Terlebih secara geografis, letak pabrik semen tersebut sudah memenuhi kualifikasi jauh dari pemukiman penduduk sebagaimana diatur dalam peraturan perundangundangan.

Akan tetapi, ada alasan tertentu mengapa pengolahan limbah menggunakan kiln semen hanya dapat digunakan sebagai strategi jangka pendek dan tidak direkomendasikan untuk digunakan terus menerus. Alasanya adalah karena limbah B3 mengandung klorin. Meskipun proses pengolahan limbah B3 dalam kiln semen dapat memusnahkan limbah dalam jumlah besar, keberadaan klorin yang berlebihan tidak hanya akan mempengaruhi kualitas semen tetapi juga pengoprasian kiln semen. Banyak penelitian menunjukan bahwa sebagian besar klorin dilepaskan dalam bentuk asam klorida (HCI) selama pembakaran limbah dilakukan. Meskipun alkalin di tanur semen dapat menetralkan sebagian besar HCI, keberadaan klorin yang berlebih dapat menyebabkan konsentrasi HCI yang berlebihan sehingga menyebabkan resistensi dioksin. Selain itu, klorin akan bereaksi dengan kalsium oksida $(\mathrm{CaO})$ yang dapat menyebabkan kelebihan frasi massa klorida dalam klinker semen (Zhu, 2019). Oleh karena itu, pemanfaatan kiln semen dalam menangani limbah B3 yang mengandung klorin tidak dapat dilakukan secara berkelanjutan melainkan hanya untuk saat mendesak ketika jumlah fasilitas insinerator yang ada berbanding terbalik dengan jumlah volume timbulan limbah yang tinggi.

Di sisi lain, dari segi pembiayaan Direktur Penilaian Kinerja Pengelolaan Limbah B3 dan Limbah Non B3, Kementerian Lingkungan Hidup dan Kehutanan (KLHK) menyatakan bahwa solusi pemecahan kesenjangan kapasitas pemusnahan limbah medis lainnya, adalah pembangunan 32 (tiga puluh dua) Fasilitas Pemusnah Limbah B3 medis di tahun 2020 - 2024 dengan APBN KLHK yang akan diserahkan dan dikelola oleh PEMDA. Akan tetapi, opsi diatas sebenarnya bukan merupakan suatu alternatif solusi yang bijak. Alasannya, penyebaran COVID-19 yang kian meluas telah menorehkan dampak yang signifikan pada segi pembiayaan. Berdasarkan laporan International Monetary Fund (IMF), pertumbuhan ekonomi global di tahun 2020, diproyeksikan akan mengalami penurunan atau minus hingga 3 persen (International Monetary Fund (IMF), 2020). Untuk Indonesia sendiri, Laurence B. dengan menggunakan NiGEM Global Macroeconomic Model, memproyeksikan pertumbuhan ekonomi di tahun 2020 akan mengalami penurunan antara $1,35-0,15$ persen. Laju pertumbuhan ekonomi Indonesia di tahun 2020, diperkirakan hanya akan menyentuh angka 4,8 persen terhadap Produk Domestik Bruto (PDB). Nilai ini jauh lebih rendah jika dibandingkan dengan pertumbuhan ekonomi pada tahun 2019, yang berada pada angka 5,02 persen (Laurence, 2020).

Sebenarnya, masih terdapat alternatif solusi lain yang dapat digunakan untuk menambah jumlah fasilitas insinerator tanpa bergantung pada APBN mengingat kondisi perekonomian yang sedang terombang-ambing. Berkaitan dengan hambatan pada segi pembiayaan, sebenarnya Indonesia dapat belajar dari China yang mengatasi keterbatasan sektor pembiayaannya dengan menerapkan Public Private Partnership (PPP) dalam bentuk Build-Operate-Transfer Agreement (selanjutnya disebut BOT) sebagai salah satu 
metode pendanaan kegiatan pengolahan limbah. BOT merupakan metode dimana pemerintah memberi wewenang kepada entitas swasta untuk mengumpulkan dana, merancang, membangun, dan mengoperasikan sebuah proyek sebelum akhirnya menyerahkan proyek tersebut kepada pemerintah. Sebelum penyerahan, BOT membuka ruang bagi pemrakarsa proyek untuk pemulihan dan pengembalian investasi serta biaya pemeliharaan yang telah dikeluarkan ( $\mathrm{Hu}, 2015)$.

Metode tersebut pertama kali diterapkan pada 2002 oleh salah satu pemerintah daerah yang memutuskan untuk bekerjasama dengan kontraktor swasta setempat yaitu Wei Ming Environmental Protection Engineering, untuk membangun dan mengoperasikan insinerator. Perusahaan a quo menginvestasikan 90 juta Chinese Yuan (CYN) terhadap fase pembangunan, pengoprasian, dan pengelolaan serta perawatan dalam kurun waktu 25 tahun (di luar 2 tahun pembangunan insinerator) yang didasarkan pada pada perjanjian BOT dan pada akhir periode, kepemilikan insinerator tersebut akan kembali ke pemerintah daerah tanpa memberikan kompensasi dalam bentuk apapun (Asian Development Bank, 2010).

\section{SIMPULAN}

Untuk merespon fenomena peningkatan volume limbah medis, Pemerintah Daerah Provinsi Jawa Barat menyarankan agar Fasyankes di Jawa Barat bekerja sama dengan PT Jasa Medivest dalam mengolah limbah B3 yang dihasilkan. Adapun metode pengolahan limbah B3 yang digunakan oleh PT Jasa Medivest adalah insinerasi dengan teknologi insenerator. Jika dilihat dari sudut pandang kelestarian lingkungan dan pembiayaan, metode tersebut memiliki beberapa kelemahan yang sebenarnya bisa direduksi jika menggunakan alternatif lain. Dari segi kelestarian lingkungan, penggunaan metode insinerasi berpotensi melanggengkan pencemaran udara karena abu yang dihasilkan dari proses pembakaran mengandung komponen zat-zat yang berbahaya bagi kesehatan makhluk hidup. Sementara itu, dari segi pembiayaan, pengolahan limbah menggunakan metode insinerasi mengeluarkan biaya yang terbilang tinggi.

Akan tetapi, sebenarnya terdapat beberapa alternatif yang dapat diterapkan untuk mengoptimalkan kegiatan pengolahan limbah B3 medis di Provinsi Jawa Barat pada era pandemi COVID-19 ini, tanpa perlu mengesampingkan aspek lingkungan dan pembiayaan. Pertama, Pemerintah Provinsi dapat mengadakan hubungan kemitraan dengan pabrik semen yang berkedudukan di wilayah Jawa Barat untuk memanfaatkan fasilitas kiln semen yang dapat digunakan sebagai subtitusi fasilitas insenerator. Kedua, daripada menggunakan APBD untuk membangun fasilitas baru di tengah kemunduran perekonomian Indonesia, ada baiknya Pemerintah Provinsi Jawa Barat dapat mempertimbangkan peluang pengaplikasian skema
Public Private Partnership dalam bentuk Build-OperateTransfer Agreement.

\section{UCAPAN TERIMA KASIH}

Rasa terima kasih Penulis sampaikan kepada semua pihak yang telah terlibat dan memberi dukungan selama pelaksanaan penelitian ini khususnya kepada dosen pembimbing yang senantiasa menjadi reviewer penelitian ini. Tidak lupa Penulis ucapkan terimakasih kepada Unit Riset dan Publikasi Fakultas Hukum Universitas Gadjah Mada (URP FH UGM) selaku pihak yang telah berkenan mendanai penelitian ini serta semua pihak yang tidak bisa Penulis sebutkan satu persatu.

\section{DAFTAR PUSTAKA}

Ali, Z. (2009). Metode Penelitian Hukum. Sinar Grafika. Jakarta

Asian Development Bank. (2010). Sustainable Urban Development in The People's Republic of China: Municipal Solid Waste Treatment: Case Study of Public-Private Partnerships (PPPs) in Wenzhou. Dipetik pada 19 Agustus 2019, dari: https://www.adb.org/publications/municipalsolid-waste-treatment-case-study-ppps-wenzhou.

Astuti, L. T. (2020). Tantangan Penanganan Limbah Medis Era Covid-19. Seminar IESA. Jakarta.

Chaerul, M., Junpi, L.L., Ekaristi, N. (2013). Meminimasi Resiko Dalam Sistem Pengelolaan Limbah Medis di Kota Bandung. Jurnal Manusia \& Lingkungan, 20(2): 137-143. DOI: https://doi.org/10.22146/jml.18480.

Chinese Government. (2020). English version of the Guide on Management \& Technical on Emergency Treatment and Disposal of Medical Waste Caused by Covid-19. Dipetik pada 16 Agustus 2020, dari: http://www.mee.gov.cn/ ywdt/xwfb/202001/t20200129_761043.shtml.

Damanhuri, E., Wahyu, I.M., Ramang, R., Padmi, T. (2009). Evaluation of Municipial Solid Waste Flow in The Bandung Metropolitan Area, Indonesia. Journal Mater Cycles Waste Manag, 11(3): 270276. DOI: https://www.doi.org/10.1007/s10163009-0241-9.

Dai, S. (2016). Optimized WtE Conversion of Municipal Solid Waste in Shanghai Applying Thermochemical Technologies. Thesis Report. Environmental Engineering, KTH School of Architecture \& the Built Environment. Stockholm.

Direktorat Jenderal Pencegahan \& Pengendalian Penyakit (P2P). (2020). Pedoman Pencegahan \& Pengendalian CORONAVIRUS DISESASE (COVID-19) Revisi ke-3. Dipetik pada 25 April 2020, dari: https://covid19.

kemkes.go.id/protokol-covid-19/kmk-no-hk-01-07menkes-413-2020-ttg-pedoman-pencegahan-danpengendalian-covid-19/.

Direktorat Penilai Kinerja Pengelolaan Limbah B3 \& Limbah Non B3. (2018). Peta Jalan (Roadmap) 
Pengelolaan Limbah B3 dari Fasilitas Pelayanan Kesehatan (Fasyankes). Kementrian Lingkungan Hidup \& Kehutanan. Jakarta.

Hamdi, A. S. (2014). Metode Penelitian Kuantitatif Aplikasi dalam Pendidikan. Deepublish. Yogyakarta.

HuMas Jawa Barat. (2020). Jabar Tangani Limbah Medis COVID-19. Diambil pada 23 Mei 2020, dari: https://jabarprov.go.id/index.php/news/37270/20 20 /04/03/Jabar-Tangani-Limbah-Medis-COVID19.

$\mathrm{Hu}, \mathrm{H}$. (2015). A Critical of Waste Incineration Plants in Wuhan (China) Based on Site Selection, Environmental Influence, Public Health \& Public Particiaption. International Journal of Environmental Research and Public Heatlh, 12(1): 7593-7614. DOI: https://doi.org/10.3390/ijerph120707593.

Ibrahim, J. (2006). Teori \& Metodologi Penelitian Hukum Normatif. Malang: Bayumedia Publishing.

International Monetary Fund (IMF). (2020, April 4). World Economic Outlook, April 2020: The Great Lock Down Chapter 1: Global Procpects \& Policies. Dipetik pada 20 Juli 2020, dari: https://www.imf.org/en/Publica tions/WEO/I ssues/2020/04/14/weo-april-2020.

Kementerian Lingkungan Hidup \& Kehutanan. KLHK Perkuat Regional Untuk Respon Limbah Infeksius COVID-19. Dipetik pada 28 Desember 2019, dari: http://ppid.menlhk.go.id/siaran_pers/browse/247 7.

Laurence. (2020). Coronavirus: The world economy at risk. France: The Organisation for Economic Cooperation \& Development (OECD).

Mohajit. (2019). Financial Prospect of The Waste to Energy Application in Solving The Most Problematic Solid Waste Management in Indonesia. Geographia Technical, 14(Special Issue): 194-200. DOI: https://www.doi.org/10.2116 3/GT_2019.141.33.
Pamungkas, Y. (2010). Teknologi Co-processing: Solusi Alternatif Mereduksi Bahan Bakar \& Gas $\mathrm{CO} 2$ di Industri Semen Indonesia. Jurnal Rekayasa Proses, 4(2): 45-50. DOI: https://doi.org/10.22146/jrekpros. 1890.

Prasetiawan, T. (2020, Mei). Permasalahan Limba Medis COVID-19 di Indonesia, Dipetik pada 25 Desember 2020, dari: http://puslit.dpr.go.id/.

Prasetiyadi., Wiharja., Wahyono, S. (2018). Teknologi Penanganan Emisi Gas dari Insinerator Sampah Kota. Jurnal Rekayasa Lingkungan, 11(2): 85-93. DOI: https://doi.org/10.29122/jrl.v11i2.3465.

Soekanto, S. (1984). Pengantar Penelitian Hukum. UIPress. Jakarta.

World Health Organization. (2020, April 4). Countries, Areas or Teritories With Cases. Dipetik pada 20 Juni 2020, dari: https://www.who.int/emergencies /diseases/novel-coronavirus-2019.

World Health Organization. (2020). Global epidemiological situation. Dipetik pada 15 Juni 2020, dari: https://www.who.int/yaws/epidemiology/en/.

Yu, H. (2020). Reverse Logistic Netrwork Design for Effective Management of Medical Waste in Epidemic Outbreaks: Insights from the Coronavirus Disease 2019 (COVID-19) Outbreak in Wuhan (China). International Journal of Environmental Research and Public Health, 17(5): 1-25. DOI: https://doi.org/10.3390/ijerph17051770.

Zhu, H. (2019, January ). Study on The Evolution \& Transformation of Chlorine During Co-Processing of Hazardous Waste Incineration Residue in a Cement Kiln. Jurnal Waste Management and Research, 37(5): 495-501. DOI: https://doi.org/10.1177/0734242X19828147. 